\title{
Wild felid diversity and activity patterns in Sabangau peat-swamp forest, Indonesian Borneo
}

\author{
Sus an M. CheYNe and David W. MaCDONALD
}

\begin{abstract}
A study to identify the felid biodiversity of the Sabangau Forest, Central Kalimantan, Indonesia, was initiated in May 2008 and involved continuous sampling until October 2009. A total of 44 cameras in 27 locations were used and 5,777 functional trap nights (of 6,542 survey nights) resulted in confirmed sightings of the Sunda clouded leopard Neofelis nebulosa, leopard cat Prionailurus bengalensis, marbled cat Pardofelis marmorata and flatheaded cat Prionailurus planiceps, representing four of the five wild felids of Borneo. The long-term use of fixed and roving cameras provided insight into the movements, occurrence and activity patterns of these elusive felids within a disturbed peat-swamp forest. In an area of $145 \mathrm{~km}^{2}$ (including buffer) the clouded leopard was the most commonly photographed felid (22 photo-captures of 53 total captures), followed by the leopard cat (21), flat-headed cat (7) and marbled cat (3). A total of 231 camera-trap nights were required to obtain the first photograph of a felid, the leopard cat, 704 for the clouded leopard, 3,498 for the flat-headed cat, and 5,423 (476 calendar days) for the marbled cat. A female clouded leopard was not photographed until 5,764 trap nights. This highlights the importance of long-term camera-trapping studies to maximize capture probability of these elusive felids and especially to account for potential differences in home range size and use by clouded leopard males and females.
\end{abstract}

Keywords Camera trapping, Indonesia, Neofelis, Pardofelis, peat-swamp forest, Prionailurus

\section{Introduction}

R ornean tropical forest contains a guild of five felid 3 species: Sunda clouded leopard Neofelis diardi (categorized as Vulnerable on the IUCN Red List; IUCN, 2010), bay cat Pardofelis badia (Endangered), marbled cat Pardofelis marmorata (Vulnerable), flat-headed cat Prionailurus planiceps (Endangered) and leopard cat Prionailurus bengalensis (Least Concern). Conducting studies on Borneo

Susan M. Cheyne* (Corresponding author) and David W. Macdonald Wildlife Conservation Research Unit, The Recanati-Kaplan Centre, Department of Zoology, Oxford University, Tubney, Abingdon Road, Tubney, OX13 5QL, UK. E-mail susan.cheyne@zoo.ox.ac.uk

${ }^{*}$ Also at: Orang-utan Tropical Peatland Project, Centre for the International Cooperation in Management of Tropical Peatlands, University of Palangka Raya, Indonesia

Received 27 October 2009. Revision requested 9 December 2009.

Accepted 22 January 2010. provides the chance to study the clouded leopard and small felid guild in the absence of competitors such as tigers Panthera tigris sumatrae and large canids, which are present throughout the remainder of the Sunda clouded leopard's range (Linkie et al., 2003; O'Brien et al., 2003).

Robust estimates of population density and population size of any of the threatened Bornean felids are lacking, particularly for Indonesian Borneo (Povey et al., 2009; Wilting et al., 2010). The extent of hunting of, or trade in, these species and their prey is unclear and the effects of different forest management regimes and habitat conversion on these felids remain unstudied. In addition, the viability of clouded leopard populations and that of the smaller felids in these threatened forests is unknown. Information on ecology, population size, distribution, behaviour and threats to the clouded leopard and other Bornean felids, and their intra- and interspecific interactions, is required to provide detailed recommendations to the appropriate authorities for the conservation of this enigmatic guild.

Thus the Sabangau Felid Project was initiated in May 2008 in a collaborative effort between the Wildlife Conservation Research Unit, Oxford, UK, Panthera and the Orang-utan Tropical Peatland Project to obtain data on the felid guild in the Sabangau catchment. Preliminary data suggested that the forest is home to a substantial population of clouded leopards (Cheyne et al., 2009; Povey et al., 2009).

A camera-trapping programme in the peat-swamp forest of Sabangau has provided the first conclusive data on four of the Bornean felids and other species in this environment, including confirmation of the presence of the flat-headed and marbled cats (Cheyne et al., 2009; Cheyne \& Macdonald, 2010) and detailed information of clouded leopard movement and density in lowland peat-swamp forest (S.M. Cheyne \& D.W. Macdonald, unpubl. data). Here we use these long-term data to examine the diversity, relative abundance and activity patterns of these felids and to provide baseline data to facilitate the conservation of these species in peat-swamp forest in Indonesian Borneo.

\section{Study area}

Sabangau is a seasonally flooded forest, underwater for 9 months each year. It is the largest area of contiguous lowland rainforest remaining in Kalimantan and is recognized as one of the most important conservation areas in Borneo for a variety of reasons, including carbon storage, regulation of water supplies and conservation of flora and fauna (MorroghBernard et al., 2003; Cheyne et al., 2007; Cheyne, 2010). The 
area has been subjected to long-term legal logging, illegal logging, fire and drainage from logging canals but is now the focus of concerted protection and restoration efforts.

The Sabangau catchment comprises $5,300 \mathrm{~km}^{2}$ of peatswamp forest between the Sabangau and the Katingan Rivers in Central Kalimantan, Indonesia (Fig. 1). The area is one of the deepest peat-swamp forests. Logging and fire have resulted in a patchwork of logged, recovering and pristine forest comprising four habitat subtypes (mixedswamp forest, transitional/mixed-swamp forest, low interior forest and tall interior forest; Page et al., 1999). Mixed-swamp forest is tall and stratified with an upper canopy of $35 \mathrm{~m}$ and a closed layer between 15 and $25 \mathrm{~m}$. The open layer is at 7-12 $\mathrm{m}$. Trees grow on large hummocks formed by root plates interspersed with hollows, which fill with water for $8-9$ months of the year. Because of logging, the undergrowth in the mixed-swamp forest study area is dense, with Pandanus and Freycinetia spp.. Transitional forest is similar to mixed-swamp forest, with a maximum canopy height of 25-30 m (Page et al., 1999). The area is still subjected to fire and illegal logging.

\section{Methods}

Twenty-two cameras were set in fixed locations for the duration of the study, with a further 22 cameras added in

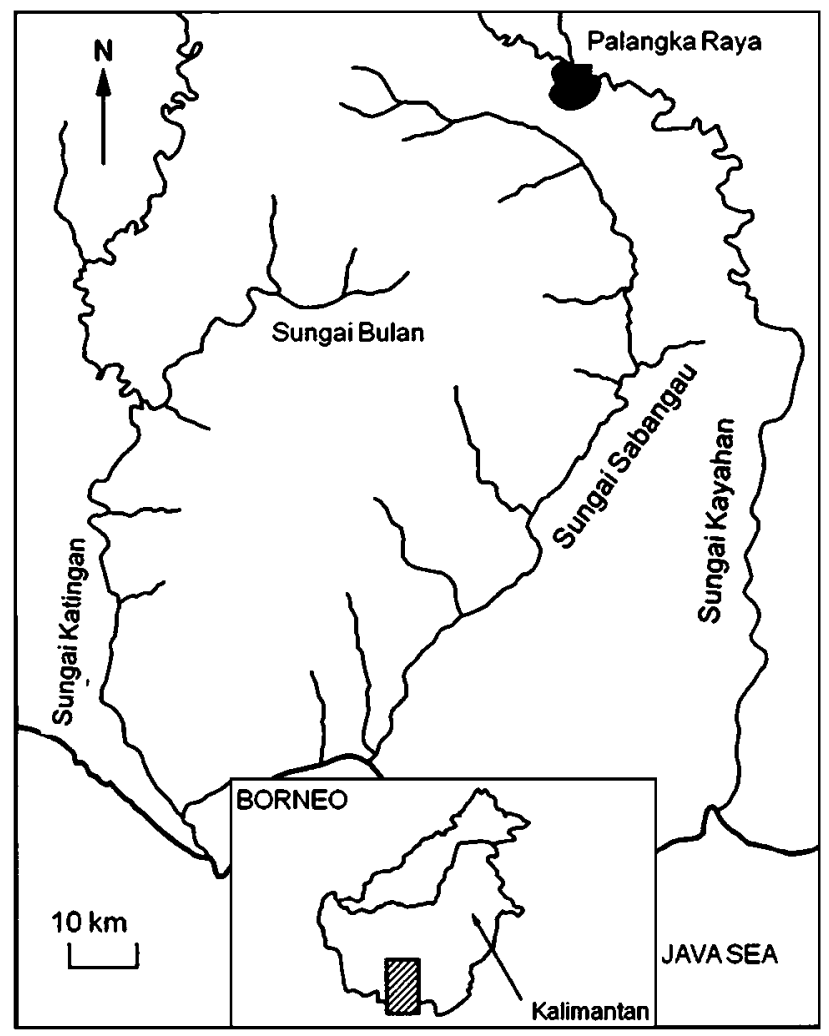

FIG. 1 The study area of Sabangau Forest. The shaded area on the main map indicates the area where camera-traps were located (Fig. 2) and the rectangle on the inset the position of the main map on Kalimantan, Indonesia.
May 2009. Of the 22 cameras placed later, 12 were placed for 45-day cycles in two additional forest areas, to increase the survey area. The 44 cameras were 22 Cuddeback Expert and 22 Cuddeback Capture IR (Cuddeback Digital; NonTypical Inc., Green Bay, USA). They were placed along established human-made trails ( $>4$ years old) and, where possible, watering areas, and located so as to maximize the success rate of photographic captures (Wilting et al., 2006; Gordon \& Stewart, 2007). At each location cameras were in pairs, 7-10 m apart, to enable each flank of any animal to be photographed simultaneously. The infrared beam was set at a height of $\mathrm{c} .50 \mathrm{~cm}$ so that the cameras would be triggered by the passage of any medium-sized mammal or bird. The Expert cameras have a pre-set minimum of 60-second delay between triggers. The change to Cuddeback Capture cameras was made when the Expert cameras started to be affected by the climate. The IR cameras have no flash and this may be better for long-term use, to avoid trap shyness from flash photography (Rowcliffe et al., 2008). There are no logging roads in the study area and all cameras were placed along established trails at crossroads or near to fallen logs or man-made boardwalks, which may facilitate travel during the flooded wet season. Because clouded leopards use regular travel routes (Wilting et al., 2006; Gordon \& Stewart, 2007) every effort was made to place cameras on established trails and only two of the 22 locations were on newly cut trails. No bait or lure was used and batteries were changed every 14 days.

All cameras were placed $0.5-5 \mathrm{~km}$ from the forest edge in previously logged mixed-swamp forest, except for one pair in mixed-swamp forest/transitional forest $5 \mathrm{~km}$ from the forest edge (Fig. 2). Cameras were not placed in deforested areas that had been burnt, because of absence of canopy cover and inaccessibility. To prevent damage by sun bears Helarctos malayanus and to enable more precise placement of cameras, all cameras were in protective boxes supported by a single wooden leg rather than being strapped to tree trunks.

The placement of camera traps was based on information on clouded leopards, which have larger ranges than the smaller felids that we also wished to investigate (Grassman, 2000; Grassman et al., 2005; Wilting et al., 2006; Gordon \& Stewart, 2007). We recognize that the minimum distance between pairs of cameras was not ideal for detecting the small-ranging species but, given the paucity of data on these felid species, all data obtained from the cameras are useful.

Only clouded leopards and leopard cats could be identified individually from the photographs. Time periods were pooled in 2-hour intervals following Azlan \& Lading (2006) and Azlan \& Sharma (2006), and activity level of a species was determined as a percentage of the total number of photographs. Nocturnal activity was categorized as that which occurred from 18.00 to 05.00 , the approximate times of sunset and sunrise in the area. 


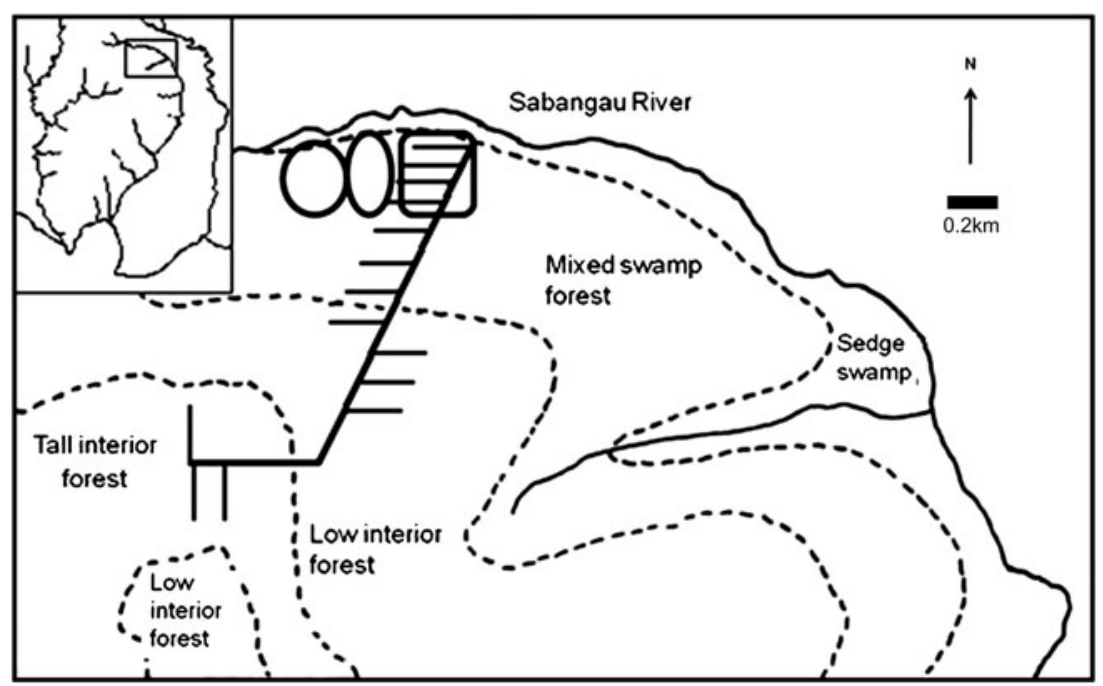

FIG. 2 Map of camera locations in mixed-swamp forest showing permanent camera locations (rectangle) and the two 45-day cycle locations (ovals). Rectangle on inset indicates the position of the main map on Fig. 1.

The capture probability at each location was not uniform (repeated measures analysis of variance, $F=0.57$, $\mathrm{df}=11, \mathrm{P}=0.822)$. This does not affect the calculation of the relative abundance index, which discounts all locations where felids have not been captured. The relative abundance index was calculated as

$$
\mathrm{RAI}=\sum_{i=1} d_{i} 100 / \sum_{i=1} \mathrm{tn}_{\mathrm{i}}
$$

where $i$ is a trap location and $t n$ is a trap night at the $i$ th location and $d$ is a detection of the species at the $i$ th location. Detection is one capture per location during one trap night (Kawanishi \& Sunquist, 2004; Azlan \& Lading, 2006; Azlan \& Sharma, 2006). This index cannot account for frequency of trail use and degree of arboreality, all of which will affect detection (Giman et al., 2007).

To calculate the relative abundance index we assumed that photographs represent independent contacts between animal and camera and that the population is closed (Rowcliffe \& Carbone, 2008; Rowcliffe et al., 2008). Repeated captures of the same individual of clouded leopard at a neighbouring or the same camera within the same day were excluded from the analysis. In studies at this small scale the relative abundance index is the only alternative in the absence of sufficient data for mark-recapture analysis.

Total functioning camera nights were calculated from the run-time of each pair of cameras, the length of time for which they were functioning, and taking into account nights when they did not function. The majority of cameras were checked before batteries failed. Total number of survey nights was 6,542, total number of functional trap nights (accounting for camera failure) were 5,777 and all cameras were in mixed-swamp forest.
In the absence of telemetry data various ad hoc approaches can be used to estimate animal range sizes and hence to estimate the area trapped. We used the mean maximum distance moved with a boundary strip width. The effective sample area was obtained using the geographical information system ArcGIS v. 9 (ESRI, Redlands, USA). The boundary strip width was added to the convex hull (minimum convex polygon) of the trap sites (i.e. the polygon that bounds the outer traps; Karanth \& Nichols, 1998).

\section{Results}

The total outer trap polygon was $7.4 \mathrm{~km}^{2}$ and when the mean maximum distance moved buffer for clouded leopards was added the total area sampled was $145.3 \mathrm{~km}^{2}$. Five of 27 camera locations, accounting for 27 of 53 (51\%) felid photo-captures were on the main trail into the forest. All photographs of felids were of single individuals. Clouded leopards were the most often detected species, with the highest relative abundance index, and marbled cats were detected least often (Table 1).

It took 231 camera trap nights ( 21 calendar days) for the first felid (the leopard cat) to be photo-trapped, 704 to trap the clouded leopard, 3,498 for the flat-headed cat and 5,423 ( 476 calendar days) for the marbled cat. A female clouded leopard was not photo-trapped until 5,764 trap nights.

The majority of the photo-captures of the clouded leopard and leopard cats were during the night (Fig. 3). Clouded leopards were the most nocturnal species $(76 \%)$, followed by leopard cats $(65 \%)$. With only seven photocaptures of flat-headed cats and three of marbled cats it is not possible to draw conclusions about their activity periods. Of 44 camera locations, felids were photographed at only 13: five camera pairs captured only one species, six 
TABLE 1 Total number of camera-trap photographs (each station did not always produce two photographs for each cat), number of confirmed individuals, the relative abundance index (see text for details), percentage of total camera-trap photographic records of felids, and percentage nocturnal activity of felid species recorded in Sabangau Forest.

\begin{tabular}{|c|c|c|c|c|c|}
\hline Species & $\begin{array}{l}\text { No. of } \\
\text { photographs }\end{array}$ & $\begin{array}{l}\text { No. of confirmed } \\
\text { individuals }\end{array}$ & $\begin{array}{l}\text { Relative abundance } \\
\text { index (photographs } \\
\text { per } 100 \text { trap nights) }\end{array}$ & $\begin{array}{l}\% \text { of } \\
\text { records }\end{array}$ & $\begin{array}{l}\% \text { nocturnal } \\
\text { activity }\end{array}$ \\
\hline Clouded leopard Neofelis diardi & 29 & $4(3 \hat{\jmath}, 1$ 운 & 2.74 & 42 & 76 \\
\hline Leopard cat Prionailurus bengalensis & 25 & $15(7 \hat{\jmath}, 5 \uparrow, 3$ unknown $)$ & 2.45 & 40 & 65 \\
\hline Flat-headed cat Prionailurus planiceps & 7 & Individuals not identified & 0.94 & 14 & 29 \\
\hline Marbled cat Pardofelis marmorata & 4 & Individuals not identified & 0.22 & 4 & 50 \\
\hline Total & 50 & 21 & 6.35 & 100 & \\
\hline
\end{tabular}

pairs captured two species and only two pairs captured three species (Table 2). No camera pair captured all four felid species. Of 14 locations where no felids were photo-captured all were in mixed-swamp forest and all but two were on established trails.

\section{Discussion}

Sabangau is home to the clouded leopard, leopard cat, flatheaded cat and marbled cat but no evidence was found of the bay cat. Rabinowitz (1989) and Azlan \& Sharma (2006) found that mainland clouded leopards are mainly diurnal (66 and $70.43 \%$, respectively) where tigers are present whereas A.J. Hearn, J. Ross \& D.W. Macdonald (unpubl. data) found that the Sunda clouded leopard is mainly nocturnal. As the Sunda clouded leopard is the largest predator on Borneo the absence of competition with tigers may allow it to be nocturnal.

All cats were photo-trapped on trails that were also used by the research team. Data from Sumatra suggest that continued presence of humans at a research site can have
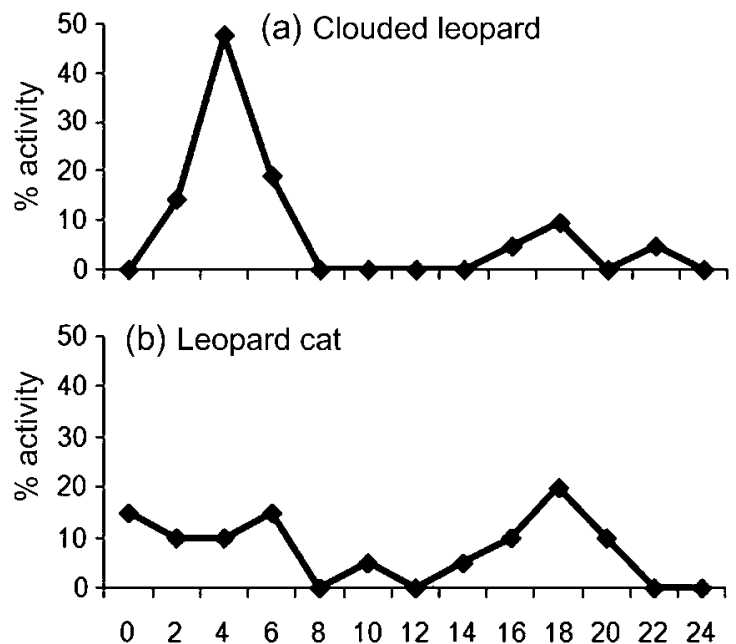

FIG. 3 Percentage activity levels over 24 hours of (a) clouded leopard Neofelis nebulosa (29 photo-captures) and (b) leopard cat Prionailurus bengalensis ( 25 photo-captures) based on pooled camera-trapping records in Sabangau Forest (Fig. 1) from May 2008 to October 2009. adverse effects, especially on large mammals (Griffiths \& van Schaik, 1993). Our study site has been in continuous use since 2003 and thus we recognize that human presence could have affected trail use by wildlife. However, the frequency of felids photographed has increased over time and we have multiple photographs of the same individual clouded leopards. Thus the felids are continuing to use the trails despite the presence of humans.

Despite the leopard cat being the most widespread and abundant felid in Borneo (Nowell \& Jackson, 1996) its

TABLE 2 Distribution of photo-captures of the four felid species (Table 1) at the 13 camera stations where felids were photographed in Sabangau Forest (all cameras were on established trails).

\begin{tabular}{|c|c|c|c|c|c|}
\hline Habitat type & $\begin{array}{l}\text { Trap } \\
\text { effort } \\
\text { (nights) }\end{array}$ & $\begin{array}{l}\text { Clouded } \\
\text { leopard }\end{array}$ & $\begin{array}{l}\text { Leopard } \\
\text { cat }\end{array}$ & $\begin{array}{l}\text { Flat- } \\
\text { headed } \\
\text { cat }\end{array}$ & $\begin{array}{l}\text { Marbled } \\
\text { cat }\end{array}$ \\
\hline $\begin{array}{l}\text { Transitional/mixed- } \\
\text { swamp forest }\end{array}$ & 364 & $\mathrm{X}$ & & & \\
\hline $\begin{array}{l}\text { Mixed-swamp } \\
\text { forest }\end{array}$ & 475 & $\mathrm{X}$ & $\mathrm{X}$ & & \\
\hline $\begin{array}{l}\text { Mixed-swamp } \\
\text { forest }\end{array}$ & 136 & $\mathrm{X}$ & & & \\
\hline $\begin{array}{l}\text { Mixed-swamp } \\
\text { forest }\end{array}$ & 437 & & $\mathrm{X}$ & $\mathrm{X}$ & \\
\hline $\begin{array}{l}\text { Mixed-swamp } \\
\text { forest }\end{array}$ & 425 & & $\mathrm{X}$ & $\mathrm{X}$ & \\
\hline $\begin{array}{l}\text { Mixed-swamp } \\
\text { forest }\end{array}$ & 322 & & & $\mathrm{X}$ & \\
\hline $\begin{array}{l}\text { Mixed-swamp } \\
\text { forest }\end{array}$ & 248 & $\mathrm{X}$ & $\mathrm{X}$ & $\mathrm{X}$ & \\
\hline $\begin{array}{l}\text { Mixed-swamp } \\
\text { forest }\end{array}$ & 465 & $\mathrm{X}$ & $\mathrm{X}$ & & \\
\hline $\begin{array}{l}\text { Mixed-swamp } \\
\text { forest }\end{array}$ & 425 & & & & $\mathrm{X}$ \\
\hline $\begin{array}{l}\text { Mixed-swamp } \\
\text { forest }\end{array}$ & 397 & $\mathrm{X}$ & & & \\
\hline $\begin{array}{l}\text { Mixed-swamp } \\
\text { forest }\end{array}$ & 232 & $\mathrm{X}$ & $\mathrm{X}$ & & \\
\hline $\begin{array}{l}\text { Mixed-swamp } \\
\text { forest }\end{array}$ & 218 & $\mathrm{X}$ & $\mathrm{X}$ & & $\mathrm{X}$ \\
\hline $\begin{array}{l}\text { Mixed-swamp } \\
\text { forest }\end{array}$ & 167 & & & & $\mathrm{X}$ \\
\hline
\end{tabular}


relative abundance index was similar to that for clouded leopards. For flat-headed and marbled cats the index is difficult to interpret because of the small sample sizes. These could be an artefact of camera placement on open trails, which may favour the larger clouded leopards (A.J. Hearn, J. Ross \& D.W. Macdonald, unpubl. data), or may represent a genuine difference in species' abundance (although the more arboreal nature of the marbled cat is a possible confounding factor). As this study was designed to maximize captures of the felid with the largest home range size, comparing the relative abundance index across species is problematic.

Two separate radio-telemetry studies in different parts of Thailand found that adult male and female clouded leopards had similar home range sizes of $30-40 \mathrm{~km}^{2}$ (using 95\% fixed kernel estimators), with smaller intensively used core areas of $3-5 \mathrm{~km}^{2}$ (Grassman et al., 2005; Austin et al., 2007). Assuming that male and female clouded leopards in Sabangau also have similar home range sizes we would have expected to capture a female clouded leopard sooner than 5,764 trap nights but three individual males were sighted before the female. Although there is usually a substantial overlap between the home ranges of male and female clouded leopards, the female could possibly have been less available to the traps because she was avoiding the territories of males, perhaps while rearing cubs. She may then have re-entered the area only once the cubs were weaned and she was receptive again. Results from Malaysian Borneo suggest that males are more likely to be photo-captured than females along roads and trails, perhaps also indicating that female clouded leopards seek to avoid encounters with males (A.J. Hearn, J. Ross \& D.W. Macdonald, unpubl. data).

Although we recorded four of the five Bornean felids in Sabangau this was only after 16 months of continuous camera-trapping. Our sample considered mostly of only mixed-swamp forest; low interior forest and tall interior forest were inaccessible because of low water in the tributary rivers and the danger of fire. For future surveys we will deploy cameras in these forest types when water levels allow access; we anticipate differences in felid usage between habitats as these habitats are either not seasonally flooded or have very low food availability. Sabangau has a history of disturbance, selective logging (legal and illegal), fire and hunting, yet the forest remains relatively contiguous, with good forest cover, which is important for conservation of felids (Nowell \& Jackson, 1996). The impact of disturbance on small forest felids is an important topic for research as these species are perhaps the most ecologically constrained, both by altitude and access to prey (Wilting et al., 2010).

This project is ongoing and our future priority is to extend surveys away from the forest edge and to interpret them in the context of surveys of hunting pressure. Much of the emphasis on the conservation of peatland biodiversity has focused on the importance of this habitat for apes. By highlighting the ecology of the felid guild we hope not only to gain greater understanding of the peatland forest ecosystem but also to draw attention to its importance for conservation. Large parts of the Sabangau forest are still being illegally logged and little is known about felid distribution throughout the rest of the forest. Although the sample sizes presented here are small, they offer additional information on these poorly understood felids and will assist in future protection of this area. The data from this study will be passed to the Indonesian Ministry for Research and Technology and translated into Indonesian for distribution to local government conservation departments so as to draw attention to the conservation importance of the peatland forest ecosystem for felids and their prey.

\section{Acknowledgements}

SMC was funded through a grant to DWM from the Kaplan family and by the Clouded Leopard Project. SMC and DWM's work on Bornean felids is part of the WildCRU-Panthera collaboration and was carried out within the OuTrop-Centre for the International Cooperation in Management of Tropical Peatlands (CIMTROP) multidisciplinary research project in the northern Sabangau Forest, Central Kalimantan, Indonesia. SMC thanks Dr Suwido Limin and CIMTROP for sponsoring her research and providing logistical support, and the contribution of all the researchers and staff who assisted with the project: Adul, Aman, Ramadhan, Santiano, Twentinolosa, Yudhi Kuswanto, Karen Jeffers, Andrea Höing, Reychell Chadwick and all the OuTrop team, and the Indonesian Ministry of Science and Technology (RISTEK) and Director General of Nature Conservation (PHKA) for permission to carry out research in Indonesia. We thank Andrew Hearn and Joanna Ross for their help throughout various stages of this project, Danica Stark for help with geographical information systems, and Andrew Hearn, Joanna Ross, Arjun Gopalaswamy, Rebecca Foster and Bart Harmsen for comments that improved this article.

\section{References}

Austin, S.C., Tewes, M.E., Grassman, L.I., Jr \& Silvy, N.J. (2007) Ecology and conservation of the leopard cat Prionailurus bengalensis and clouded leopard Neofelis nebulosa in Khao Yai National Park, Thailand. Acta Zoologica Sinica, 53, 1-14.

Azlan, J.M. \& LAding, E. (2006) Camera trapping and conservation in Lambir Hills National Park, Sarawak. Raffles Bulletin of Zoology, 54, 469-475.

Azlan, J.M. \& Sharma, D.S.K. (2006) The diversity and activity patterns of wild felids in a secondary forest in Peninsular Malaysia. Oryx, 40, 36-41.

Cheyne, S.M. (2010) Behavioural ecology and socio-biology of gibbons (Hylobates albibarbis) in a degraded peat-swamp forest. 
In Indonesian Primates (eds J. Supriatna \& S.L. Gursky), pp. 121156. Springer, New York, USA.

Cheyne, S.M. \& Macdonald, D.W. (2010) Confirmed presence of marbled cat in Sabangau peat-swamp forest, Indonesian Borneo. Cat News, 52, 11.

Cheyne, S.M., Morrogh-Bernard, H. \& Macdonald, D.W. (2009) First flat-headed cat from Sabangau peat-swamp forest, Indonesian Borneo. Cat News, 51, 18.

Cheyne, S.M., Thompson, C.J.H., Phillips, A.C., Hill, R.M.C. \& Limin, S.H. (2007) Density and population estimate of gibbons (Hylobates albibarbis) in the Sabangau catchment, Central Kalimantan, Indonesia. Primates, 49, 50-56.

Giman, B., Stuebing, R., Megum, N., McShea, W.J. \& Stewart, C.M. (2007) A camera trapping inventory for mammals in a mixed use planted forest in Sarawak. Raffles Bulletin of Zoology, $55,209-215$.

Gordon, C.H. \& StewarT, A.-M.E. (2007) The use of logging roads by a solitary felid, the clouded leopard. Cat News, 47, 12-13.

Grassman, L.I. (2000) Movements and diet of the leopard cat Prionailurus bengalensis in a seasonal evergreen forest in southcentral Thailand. Acta Theriologica, 45, 421-426.

Grassman, L.I., Tewes, M.E., Silvy, N.J. \& Kreetiyutanont, K. (2005) Ecology of three sympatric felids in a mixed evergreen forest in north-central Thailand. Journal of Mammalogy, 86, 29-38.

Griffiths, M. \& van Schaik, C.P. (1993) The impact of human traffic on the abundance and activity periods of Sumatran rain forest wildlife. Conservation Biology, 7, 623-626.

IUCN (2010) IUCN Red List of Threatened Species v. 2010.2. Http:// www.iucnredlist.org [accessed 27 July 2010].

Karanth, K.U. \& Nichols, J.D. (1998) Estimation of tiger densities in India using photographic captures and recaptures. Ecology, 79, 2852-2862.

Kawanishi, K. \& Sunquist, M.E. (2004) Conservation status of tigers in a primary rainforest of Peninsular Malaysia. Biological Conservation, 120, 329-344.

Linkie, M., Martyr, D.J., Holden, J., Yanuar, A., Hartana, A.T., Sugardjito, J. \& Leader-Williams, N. (2003) Habitat destruction and poaching threaten the Sumatran tiger in Kerinci Seblat National Park, Sumatra. Oryx, 37, 41-48.

Morrogh-Bernard, H., Husson, S., Page, S.E. \& Rieley, J.O. (2003) Population status of the Bornean orang-utan (Pongo pygmaeus) in the Sabangau peat swamp forest, Central Kalimantan, Indonesia. Biological Conservation, 110, 141-152.

Nowell, K. \& Jackson, P. (1996) Wild Cats: Status Survey and Conservation Action Plan. IUCN, Gland, Switzerland.
O’Brien, T.G., Kinnaird, M.F. \& Wibisono, H.T. (2003) Crouching tigers, hidden prey: Sumatran tiger and prey populations in a tropical forest landscape. Animal Conservation, 6, 131-139.

Page, S.E., Rieley, J.O., Shotyк, Ø.W. \& Weiss, D. (1999) Interdependence of peat and vegetation in tropical peat swamp forest. Philosophical Transactions of the Royal Society: Biological Sciences, 354, 1885-1897.

Povey, K., Howard, J.G., Sunarto, Priatna, D., Ngoprasert, D., ReEd, D. et al. (2009) Clouded Leopard and Small Felid Conservation Summit Final Report. IUCN/SSC Conservation Breeding Specialist Group, Apple Valley, USA.

Rabinowitz, A.R. (1989) The density and behaviour of large cats in a dry tropical forest mosaic in Huai Kha Khaeng Wildlife Sanctuary, Thailand. Natural History Bulletin of the Siam Society, $37,235-251$.

RowCliffe, J.M. \& CARbone, C. (2008) Surveys using camera traps: are we looking to a brighter future? Animal Conservation, 11, 185186.

Rowcliffe, J.M., Field, J., Turvey, S.T. \& Carbone, C. (2008) Estimating animal density using camera traps without the need for individual recognition. Journal of Applied Ecology, 45, 1228-1236.

Wilting, A., Cord, A., Hearn, A.J., Hesse, D., Mohamed, A., TRAEHOLDT, C. et al. (2010) Looking for a home for flat-headed cats; modelling the species distribution of an endangered SouthEast Asian small cat species. PLoS One, 5(3), doi:10.1371/ journal.pone.0009612.

Wilting, A., Fischer, F., BaKar, S.A. \& Linsenmair, K.E. (2006) Clouded leopards, the secretive top-carnivore of South-East Asian rainforests: their distribution, status and conservation needs in Sabah, Malaysia. BMC Ecology, 6, 1-27.

\section{Biographical sketches}

Susan M. Cheyne has worked in Indonesia since 2002 and is leading a long-term study of gibbon behaviour and ecology in peatswamp forest as well as carrying out a detailed study of felid biodiversity and conservation in the area. She has carried out surveys on flying fox hunting and abundance and is interested in how anthropogenic factors affect biodiversity in peat-swamp forest. David W. Macdonald is director of WildCRU. His background is in behavioural ecology, with an emphasis on carnivores, and his interests span studies on organisms from moths to penguins and even, occasionally, plants. 